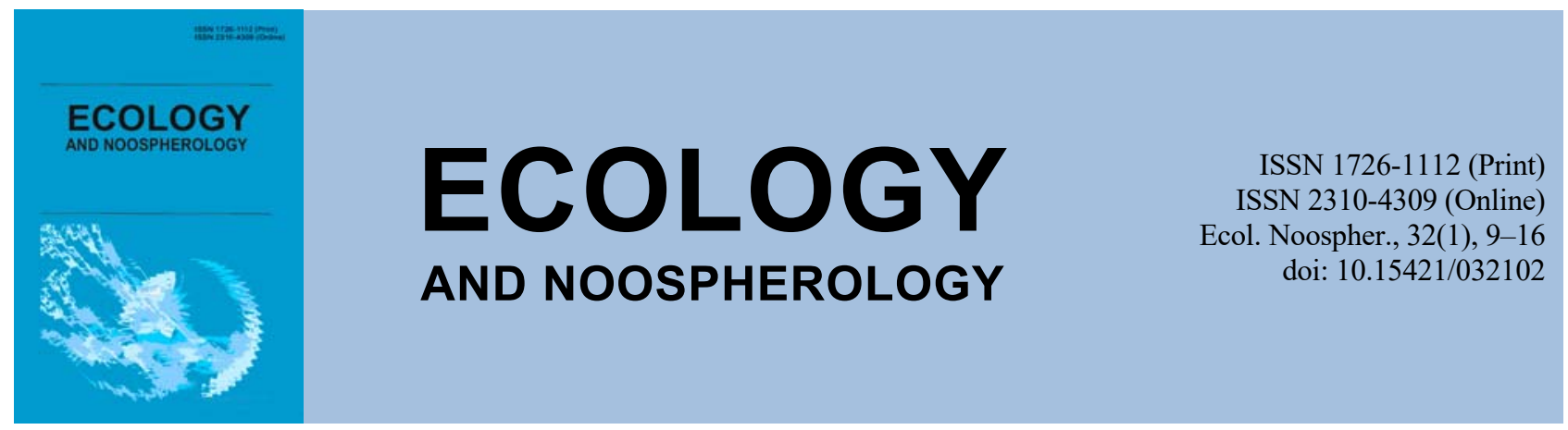

\title{
Indices of the DNA repair system in the brain of fish as a biomarker of inorganic mercury burden
}

\author{
V. S. Nedzvetsky***, V. Ya. Gasso*, R. O. Novitskyi***, I. A. Hasso* \\ * Oles Honchar Dnipro National University, Dnipro, Ukraine \\ **Bingöl University, Bingöl, Turkey \\ ***Dnipro State Agrarian and Economic University, Dnipro, Ukraine
}

Article info

Received 07.05.2021

Received in revised form 11.05.2021

Accepted 22.05.2021

Oles Honchar Dnipro

National University

Gagarin Ave., 72, Dnipro, 49010, Ukraine.

Tel.: +38-097-302-56-83

E-mail:viktor.gasso@gmail.com

Bingöl University,

Selahaddin-i Eyyubi Mah.

Üniversite Cad. No 1,

Bingöl, 12000, Turkey.

Dnipro State Agrarian and Economic University,

Serhiy Yefremov Str., 25,

Dnipro, 49600, Ukraine.
Nedzvetsky, V. S., Gasso, V. Ya., Novitskyi, R. O., Hasso, I. A. (2021). Indices of the DNA repair system in the brain of fish as a biomarker of inorganic mercury burden. Ecology and Noospherology, 32(1), 9-16. doi:10.15421/032102

Mercury is a widespread heavy metal that causes a stable and prolonged environmental pollution. Low concentrations of inorganic and organic mercury compounds are found in almost all water bodies. The high level of mercury bioaccumulation is a cause of tissue-specific toxicity, including neurotoxicity. Absorbed in nervous tissue mercury can cause brain disorders both in neural and glial cells. The brain of fish is considered one of the most susceptible targets for cytotoxicity of mercury in aquatic ecosystems. Taking into account that different forms of mercury have widespread distribution and exhibit a strong neurotoxic effect, the assessment of mercury cytotoxicity in the brain of fish is relevant and extremely important. Rainbow trout Oncorhynchus mykiss was exposed to mercury chloride in the dose range of $5-20 \mu \mathrm{g} / \mathrm{L}$ for 60 days to study the chronic exposure of low doses. In this paper, we studied the influence of inorganic mercury on oxidative stress, DNA repair proteins - ERCC1 and PARP1 in the trout's brain. The results obtained have shown that the chronic effect of inorganic mercury causes dosedependent oxidative stress in the fish brain. In addition, low concentrations of mercury (10 and $20 \mu \mathrm{g} / \mathrm{L}$ ) caused a decrease in the content of ERCC1 in the brain of fish. On the contrary, the same doses have caused an increase in PARP1 expression. That is the chronic influence of low concentrations of inorganic mercury has a negative effect in the fish brain. Observed results showed that inorganic mercury has a potential for suppressing DNA repair and, therefore, increases the instability of genome. Thus, ERCC1 and PARP1 can be considered as the sensitive biomarkers of mercury cytotoxicity in the fish brain. A further study of mercury neurotoxicity is needed to find out the hazard of mercury environmental pollution as well as a validation of biomarkers of their impact.

Keywords: rainbow trout; Oncorhynchus mykiss; heavy metal, oxidative stress; reactive oxygen species; ROS; ERCC; PARP

\section{Показники ДНК-репараційної системи у мозку риб як біомаркер навантаження неорганічною ртуттю}

\author{
В. С. Недзвецький*,**, В. Я. Гассо*, Р. О. Новіцький***, І. А. Гассо* \\ *Дніпровський національний університет імені Олеся Гончара, Дніпро, Україна \\ **Бінгьольський університет, Бінгьол, Туреччина \\ ***Дніпровський державний аграрно-економічний університет, Дніпро, Украӥна
}

Ртуть є повсюдно поширеним елементом, який викликає стабільне і тривале забруднення навколишнього середовища грунтів і вод. Низькі концентрації неорганічних та органічних сполук ртуті знаходять майже у всіх водних об'єктах. Високий рівень біоакумуляції ртуті $\epsilon$ основною причиною тканинно-специфічної токсичності, включаючи нейротоксичність. Абсорбована нервовою тканиною ртуть може викликати порушення роботи мозку як у нейронних, так і в гліальних клітинах. Мозок риб вважається однією з найбільш сприйнятливих мішеней для цитотоксичності ртуті. Беручи до 
уваги, що різні форми ртуті мають широке розповсюдження і виявляють сильний нейротоксичний ефект, оцінка цитотоксичності ртуті в мозку риб є актуальною та надзвичайно важливою. Райдужну форель (Oncorhynchus mykiss) піддавали впливу хлориду ртуті в діапазоні доз 5-20 мкг/л протягом 60 діб для вивчення хронічного впливу низьких доз. Ми вивчали вплив неорганічної ртуті на окислювальний стрес, білок ексцизійної репарації ДНК ЕRСС1 та полі(АДФ-рибозо)полімеразу 1 (PARP1) у мозку райдужної форелі. Отримані результати дослідження показали, що хронічний вплив неорганічної ртуті викликає дозозалежний окислювальний стрес у мозку риб. Крім того, низькі концентрації ртуті (10 та 20 мкг/л) викликали зниження вмісту ERCC1 у мозку риб. Навпаки, ці ж дози викликали збільшення експресії PARP1. Тобто хронічний вплив низьких концентрацій неорганічної ртуті чинить негативний ефект у мозку риб. Спостережувані результати показали, що неорганічна ртуть має потенціал для пригнічення репарації ДНК i, отже, підвищує нестабільність геному. Таким чином, ERCC1 i PARP1 можна вважати чутливими біомаркерами цитотоксичності ртуті в мозку риб. Необхідне подальше вивчення нейротоксичності ртуті для з'ясування потенційного ризику забруднення навколишнього середовища сполуками, що містять ртуть, а також валідацією біомаркерів їх впливу на організми.

Ключові слова: райдужна форель; Oncorhynchus mykiss; важкі метали; окислювальний стрес; реактивні сполуки кисню; PCK; ERCC; PARP

\section{Вступ}

Важкі метали - одні з пріоритетних забруднювачів навколишнього середовища, які можуть викликати негативні наслідки у головному мозку тварин (Kirici et al., 2019; Gasso et al., 2020; Nedzvetsky et al., 2020a; 2020b). Ртуть визнана одним з найбільш токсичних важких металів для всіх типів живих організмів (Has-Schön et al., 2015). Глобальний технологічний прогрес хімічної та важкої промисловості став однією 3 критичних причин забруднення природних водойм важкими металами (Meena et al., 2017). Зростаючий видобуток корисних копалин, спалювання органічного палива, скидання міських відходів та промислові викиди разом створюють значне збільшення забруднення довкілля ртуттю у всьому світі (Horowitz et al., 2014; Obrist et al., 2018). Низькі концентрації сполук ртуті присутні у багатьох водних об'єктах. Вміст ртуті, що перевищував гранично допустимі концентрації, виявлено в донних відкладеннях та водах майже в усьому світі (Eagles-Smith et al., 2016a: Eagles-Smith et al., 2016b). Високий показник біоакумуляції, особливо для водних екосистем, робить цей метал надзвичайно небезпечним та опосередковує іiі надзвичайно високу токсичність (EaglesSmith et al., 2016b; Orihel et al., 2007). Визначені численні клітинні пошкодження, що супроводжують біоакумуляцію ртуті у риб (Carocci et al., 2014; Chang et al., 2017), яка накопичується у зябрах, нирках, печінці, м'язах та мозку (Simon, Boudou, 2001; Amlund et al., 2007; Vieira et al., 2009; Brandão et al., 2015; Gómez -Olivan et al., 2017).

Відомо, що органічна ртуть може відносно легко перетинати гематоенцефалічний бар'єр (ГЕБ) (Wang, Wong, 2003; Pletz et al., 2016, Cariccio et al., 2019) i проявляти виражену цитотоксичність у клітинах нервової тканини (Carocci et al., 2014). 3 іншого боку, виявилося, що накопичення органічної ртуті в мозку риб не залежить від співвідношення органічної та неорганічної ртуті у воді та відстані від джерела забруднення (Pereira et al., 2014). Неорганічна ртуть може безпосередньо взаємодіяти 3 клітинами, які беруть участь у бар'єрних функціях, i порушувати цілісність ГЕБ (Zheng et al., 2003), що підтверджується наявністю і неорганічної ртуті в мозку риб (Mieiro et al., 2011; Harayashiki et al., 2019; Pereira et al., 2016) та накопиченням неорганічної ртуті в астроцитах, пов'язаних з ГЕБ (Lohren et al., 2015). Продемонстровано також відтермінований вплив неорганічної ртуті на мозок риб (Pereira et al., 2015).

Інша важлива особливість ртуті опосередкована іi спорідненістю до гемоглобіну, що може індукувати гіпоксичні ушкодження у клітинах мозку (Giblin, Massaro, 1975). Дослідження in vivo та in vitro показали високу гостру токсичність ртуті для риб (Pereira et al., 2019). Абсорбція неорганічної ртуті може призвести до затримки термінів прояву шкідливих наслідків для мозку через час, необхідний для трансформації такої форми ртуті в органічну шляхом метилювання. Таким чином, цитотоксичність хронічних ефектів неорганічної ртуті має бути оцінена 3 урахуванням трансформації певної іï частини в органічну форму. Механізми транспортування та накопичення органічних та неорганічних форм ртуті в клітинах мозку залишаються дискусійними (Aschner, Aschner 1990; Pereira et al., 2019). Показано, що органічна ртуть виявляє значно вищу цитотоксичність щодо клітин ГЕБ (Lohren et al., 2016). 3 іншого боку, неорганічна ртуть виявляється більш токсичною щодо нейронів та гліальних клітин (Lin et al., 2021). Незважаючи на велику кількість досліджень щодо токсичності ртуті у різних організмів, механізми іiі нейротоксичності залишаються нерозкритими повністю. Крім того, не зрозумілим $є$ цитотоксичний ефект неорганічної ртуті у мозку риб, які розглядаються як критична мішень акумуляції ртуті та $\epsilon$ продуктом харчування людини.

Відомі генотоксичні ефекти сполук ртуті в мозку риб, які проявляються у розривах ДНК та/або конденсації хроматину (Pereira et al., 2010; Hussain et al., 2018). Виявлено зв'язок між генотоксичністю та оксидативним стресом у риб, індукованим ртуттю (García-Medina et al., 2017). Однак молекулярні механізми репарації ДНК у риб за умов впливу низьких доз ртуті не досліджені. Усі еукаріотичні клітини мають декілька систем репарації ушкоджень ДНК. Зокрема, білок ексцизійної репарації крос-комплементинг 1 (ERCC1) забезпечує один 3 важливих механізмів відновлення ДНК вирізанням нуклеотидів. ДНК ушкодження активують ERCC1, що, у свою чергу, ініціює каскадний процес ексцизійної репарації нуклеотидів (NER). В останні роки розглядається використання ERCC1 як біомаркера виживаності клітин (Koutsoukos et al., 2020). У той же час відсутні дані про експресію ERCC1 в організмі риб, експонованих сполуками ртуті, які мають генотоксичний ефект.

Іншим універсальним механізмом репарації ДНК $\epsilon$ полі-АДФ-рибозолювання, один з видів посттрансляційної модифікації білків, що каталізується полі(АДФ-рибозо)полімеразою 1 (PARP1) та сприяє залученню інших систем репарації (Bock, Chang, 2016). Експресія PARP1 також раніше не досліджувалася в тканинах риб, зокрема мозку, за умов інтоксикації сполуками ртуті.

Про можливі механізми нейротоксичності метилртуті повідомлялося у дослідженнях як in vivo, так $\mathrm{i}$ in vitro. Порушення проникності та інтегративних властивостей ГЕБ, що пов'язане 3 підвищенням рівня ендотеліального фактору росту судин, продемонстровано в моделі хронічної інтоксикації щурів (Takahashi et al., 2017). Однією 3 добре вивчених патологій, що викликаються ртуттю в мозку, $€$ неспецифічне окислювальне пошкодження мембранних структур, білків і ДНК (Valavanidis 2006). Саме через слабку антиоксидантну властивість клітини нервової тканини мають високу чутливість до токсичної дії ртуті (Simmons et al., 2011). Окремі автори пропонували використовувати індекси окисно-відновного балансу і антиоксидантної системи як біомаркер токсичності навколишнього середовища, забрудненого сполуками ртуті (van der Oost et al., 2003; 
Santovito et al., 2012). Однак важливо зазначити, що антиоксидантна реакція залежить від різних факторів і не залежить від природи індуктора-забруднювача (Valavanidis, 2006; Pillet, 2019). Дійсно, вимірювання показників окисного стресу може бути важливим доповненням до вивчення багатофакторного впливу забруднення навколишнього середовища (Dos Santos et al., 2018). Таким чином, дослідження цитотоксичних ефектів ртуті у мозку риб дозволить розкрити молекулярні механізми генотоксичності та оцінити використання білків репарації ДНК як біомаркерів забруднення навколишнього середовища ртуттю. До того ж, вивчення нейротоксичності ртуті для водних організмів є актуальним і важливим для розуміння шкідливих наслідків забруднення поверхневих вод.

Райдужна форель $є$ загальноприйнятим об'єктом для вивчення впливу різних забруднювачів навколишнього середовища, включаючи ртуть (Liu et al., 2013; Kenšová et al., 2012; Ciardullo et al., 2008). Застосування експериментальної моделі для вивчення ефекту різних доз ртуті дозволяє виявити молекулярні механізми тканинноспецифічних порушень, які можуть ініціювати клітинну загибель та втрату функціонування.

Метою нашого дослідження є 3'ясування механізму генотоксичності і ролі ERCC1 та PARP1 у реакції клітин нервової тканини риб на нейротоксичний вплив неорганічної ртуті.

\section{Матеріали та методи досліджень}

Модель токсичного впливу неорганічної ртуті на риб. Експериментальне вивчення нейротоксичної дії неорганічної ртуті на мозок риб проведено в лабораторії молекулярної біології та генетики Бінгьольського університету, Туреччина. Пструг (форель) райдужний (Oncorhynchus mykiss (Walbaum, 1792)) $(47,1 \pm 2,73$ г i $12,1 \pm 1,07 \mathrm{~cm})$ була придбана у рибницькому господарстві Кебан, провінція Елазиг. Привезених до лабораторії риб помістили в 200-літрові акваріуми для акліматизації протягом 20 діб. Рибу годували комерційним кормом у кількості $2 \%$ до їх маси тіла двічі на день. Температуру води підтримували на рівні $17 \pm 2{ }^{\circ} \mathrm{C}$, розчиненого кисню $8,24 \pm 0,5$ мг/л та $\mathrm{pH} 7,3 \pm 0,2$. Відповідно попередньо отриманого райдужної форелі значення LD50 (276 мкг/л) для груп обрали низькі дози хлориду ртуті $\left(\mathrm{HgCl}_{2}\right) 5,10$ та 20 мкг/л. Хронічну експозицію ртуттю здійснювали протягом 60 діб (Taysi et al., 2019). Відповідні концентрації $\mathrm{HgCl}_{2}$ підтримували шляхом заміни $30 \%$ об'єму води, що містила 5, 10 та 20 мкг/л хлориду ртуті двічі на тиждень. У контрольній групі заміну $30 \%$ об'єму води проводили так само, але без додавання $\mathrm{HgCl}_{2}$. Кожна група риб, як контрольна, так і три експериментальні групи, складались 3 восьми особин. Вихідна концентрація ртуті у воді, яку використовували для проведення експерименту, не перевищувала 0,5 мкг/л.

Відбір проб тканин. Після проведення експерименту риб декапітували 3 дозволу і відповідно до протоколів Комітету з біоетики Бінгьольського університету. Мозок видаляли і промивали охолодженим фосфатним буферним розчином (PBS). Отримані зразки мозку одразу заморожували при мінус $80^{\circ} \mathrm{C}$ і зберігали до екстракції зразків білка.

Гомогенізація тканин. Екстракцію білка 3 тканин мозку проводили індивідуально для кожного індивідууму. Кожен зразок тканини гомогенізували у співвідношенні 1:15 (мас./об.) з використанням буфера для лізису, що містив 10 мМ трис-буфера (pH =7,4), 0,1 мМ NaCl, $1 \%$ TritonX-100, 0,2 \% SDS, 2,5 мМ етилендіамінтетраоцтової кислоти (EDTA), 6,5 мкМ апротиніну, 1,5 мкМ пепстатину A, 23 мкМ лейпептину, 1 мМ фенілметилсульфонілфториду (PMSF), 1 мкM ортованадату натрію 5 мкМ соєвого інгібітору трипсину. Процедури гомогенізації проводили на льоду, щоб запобігти розщепленню білка, викликаному протеазами. Після гомогенізації отримані суспензії інкубували на льоду 60 хв для екстрагування білків. Гомогенати після інкубації центрифугували при $60000 \mathrm{~g}$ протягом 45 хв у охолодженій центрифузі. Супернатанти, які містили екстракт загального білка, переносили до мікроцентрифужних пробірок та зберігали при $-80^{\circ} \mathrm{C}$ перед проведенням імуноблотингу.

Визначення вмісту реактивних сполук кисню. Рівень реактивних сполук кисню (РСК) вимірювали індивідуально в кожному супернатанті проби тканини мозку риб контрольної та експериментальних груп, які експонували різними дозами ртуті. Уміст РСК вимірювали за допомогою флуорометричного методу на основі реакції 2',7'-дихлорфлуоресцину діацетату (DCFHDA). Супернатант (200 мкл) змішували з 10 мкM DCFHDA та інкубували 30 хв при $37^{\circ} \mathrm{C}$. Вимірювання рівнів РСК проводили за допомогою спектрофлюориметра SpectraMax Gemini EM iз довжиною хвилі збудження 485 нм та випромінювання 530 нм. Кожну процедуру проводили 3 використанням тест-набору для аналізу вмісту РСК. Кожен зразок тестували у потрійних паралелях.

Аналіз експресї̈ ERCC1 ma PARPI методом імуноблотингу. Імуноблотинг проводили за допомогою розподілу білків у SDS-PAG електрофорезі з 5 - 20\%-ним градієнтом акриламіду. Розділені в поліакриламідному гелі білки переносили електричним полем $20 \mathrm{~B} / \mathrm{cm}$ протягом 120 хв на мембрану 3 полівініліденфториду (PVDF). Мембрану промивали PBS та інкубували у блокувальному трис-сольовому буфері (TBST), що містив 0,05\% Твін-20 та $3 \%$ бичачого сироваточного альбуміну (BSA) протягом 60 хв. Після блокування мембрани інкубували протягом ночі при $+4{ }^{\circ} \mathrm{C}$ з розчином первинних антитіл, анти-ERCC1 (Abcam, ab129093, розведення 1:3000), анти-PARP1 (Abcam, ab32071, розведення 1:3000) та анти- $\beta$-актин у якості контрольного білка (Abcam, ab8226, розчин 1: 5000). Після інкубації з первинними антитілами мембрану тричі промивали TBST. Промиті мембрани інкубували 3 відповідними антикролячими або антимишачими HRPміченими вторинними антитілами протягом 60 хв за кімнатної температури. Після зондування вторинних антитіл мембрани промивали тричі тим же TBST. Результати вестерн-блотингу визначені за допомогою набору ECL на основі методу хемілюмінесценції за допомогою автоматичного рентгенівського апарату проявлення плівок (Carestream Health Inc., США).

Денситометричний аналіз зон імунозабарвленого поліпептиду проводили за допомогою програмного забезпечення TotalLab TL120 (США). Значення інтенсивності, отримане під час сканування кожної окремої смуги, було нормалізоване до інтенсивності щодо відповідної смуги актину. Кожен трек на відсканованому зображенні був скоригований до рівня фону, який відповідає нереактивній області на рентгенівській плівці.

Статистичний аналіз. Статистичний аналіз отриманих результатів проводили 3 використанням дисперсійного аналізу (ANOVA) 3 подальшим пост-хоктестом Бонферроні. Дані виражені як середнє значення (М) \pm стандартна похибка (SEM) щонайменше 3 восьми незалежних експериментів. Значення $\mathrm{p}<0,05$ були прийняті як статистично значущі.

\section{Результати та їх обговорення}

Надмірна продукція РСК та зростання окисного стресу визнаються загальним наслідком впливу іонів різних важких металів. Для того щоб дослідити хронічний вплив низьких доз ртуті на клітини нервової тканини, вимірювали рівень РСК у гомогенатах зразків мозку риб. Залежне від концентрації збільшення вмісту РСК спостерігалося у всіх груп риб, яких утримували в експериментальних умовах експозиції концентраціями 5- 
20 мкг/л неорганічної ртуті (рис. 1). Однак статистично значущі відмінності продукування РСК були визначені в мозку риб, які були експоновані дозами 10 і 20 мкг/л неорганічної ртуті.

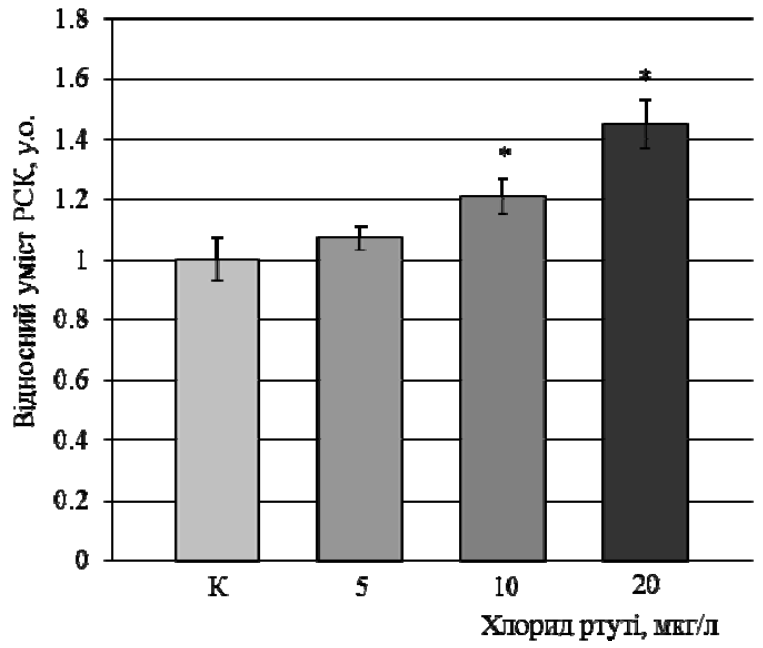

Рис. 1. Рівень РСК у мозку райдужної форелі під впливом 5, 10 та 20 мкг/л хлориду ртуті, $\mathrm{M} \pm \mathrm{SEM} ;{ }^{*} \mathrm{p}<0,05$ порівняно з контрольною групою

Згідно 3 метою дослідження, для того щоб виявити можливий генотоксичний вплив неорганічної ртуті на мозок риб, відносний уміст ERCC1 був визначений за допомогою вестерн-блотингу в екстрактах білка мозку форелі контрольної та експериментальних груп. Зниження експресії ERCC1 спостерігалося у риб в групах, які піддавалися дії 10 та 20 мкг/л (рис. 2, 4). 3 іншого боку, порівняно 3 контрольною групою не було виявлено статистично значущих змін у риб з групи, яка отримувала дозу 5 мкг/л.

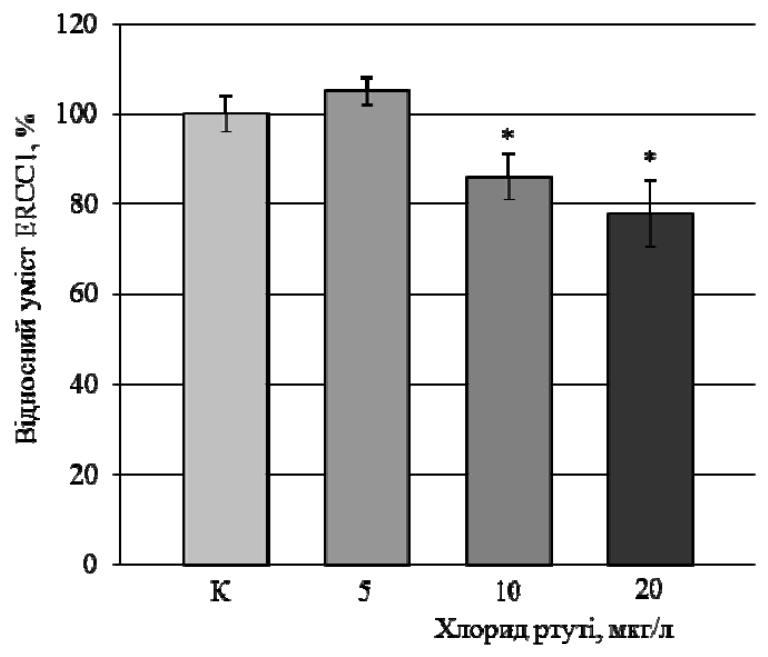

Рис. 2. Експресія ERCC1 у мозку райдужної форелі під впливом 5, 10 та 20 мкг/л хлориду ртуті, $\mathrm{M} \pm \mathrm{SEM}$; $* \mathrm{p}<0,05$ порівняно $з$ контрольною групою

Враховуючи факт, що PARP1 $є$ визнаним ключовим фактором клітинної відповіді на різні цитотоксичні фактори, у роботі досліджували експресію PARP1 у мозку риб, щоб з'ясувати роль PARP1 у нейротоксичності, спричиненій ртуттю. Збільшення вмісту PARP1 було виявлено у групі риб, експонованих дозою 20 мкг/л протягом 60 діб (рис. 3, 4). На відміну від цієї групи, експозиція дозами 5 та 10 мкг/л не викликала статистично достовірних змін умісту PARP1 в мозку риб.

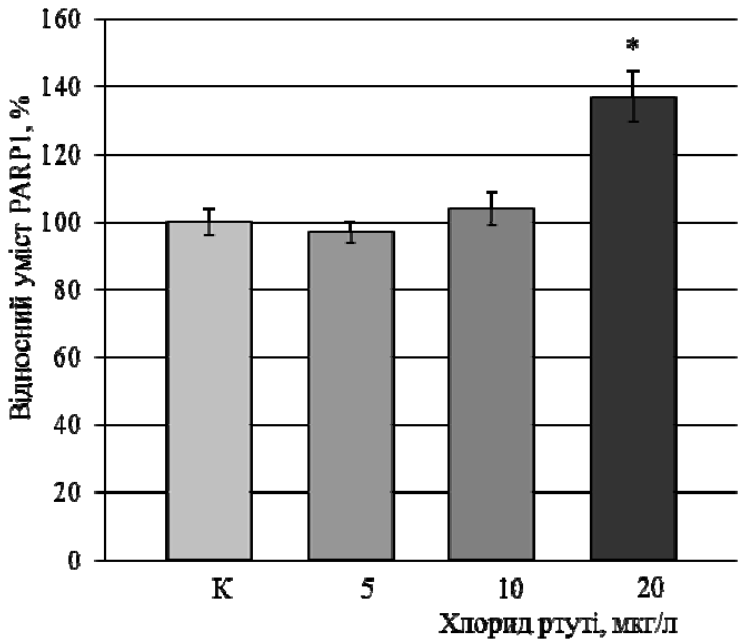

Рис. 3. Вміст PARP1 у мозку райдужної форелі під впливом 5, 10 та 20 мкг/л хлориду ртуті, $\mathrm{M} \pm \mathrm{SEM}$;

$* \mathrm{p}<0,05$ порівняно $з$ контрольною групою

Враховуючи результати, отримані у нашому дослідженні, цитотоксичність низьких доз неорганічної ртуті супроводжується дозозалежним збільшенням рівня РСК у мозку райдужної форелі за умов дії неорганічної ртуті у низьких дозах протягом 60 діб. До того ж, хронічний вплив низьких доз хлориду ртуті індукував порушення експресії критичних регуляторів клітинної відповіді на ушкодження ДНК з вираженим реципрокним ефектом. У нашому дослідженні виявлено зниження експресії ERCC, що супроводжувалось зростанням експресії PARP1 у мозку райдужної форелі (рис. $2,3,4$ ).
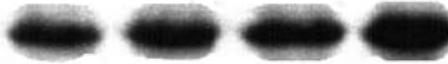

PARP1, 116 кДа

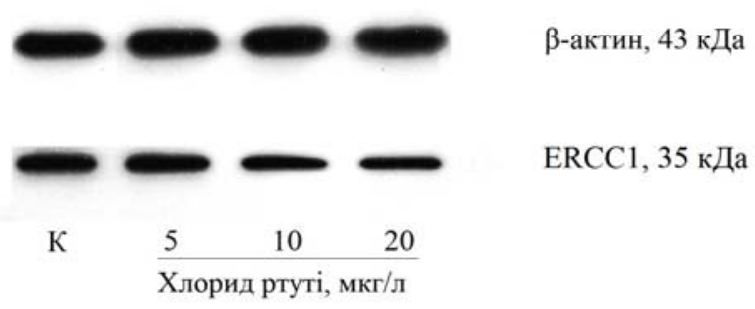

Рис. 4. Результати імуноблотингу ERCC1 та PARP1 у мозку райдужної форелі. К - контрольна група; 5, 10, 20 - експериментальні групи риб, яких піддавали дії 5, 10 та 20 мкг/л хлориду ртуті

Отримані в представленому дослідженні результати вказують на певний ризик хронічного впливу низьких доз неорганічних сполук ртуті через їх нейротоксичну дію в мозку риб.

Глобальне забруднення навколишнього середовища важкими металами індукує велику кількість порушень, спричинених множинними цитотоксичними ефектами в piзних тканинах майже всіх живих організмів (Leonard et al., 2004). В останні десятиліття досліджені шкідливі ефекти різних форм ртуті. Незважаючи на наявність експериментальних даних, конкретні молекулярні механізми нейротоксичної дії ртуті досі недостатньо зрозумілі. Ртуть підтверджена як надзвичайно небезпечний фактор для здоров'я людей та тварин (Carocci et al., 2014). Дані вказують, що токсичність неорганічної ртуті, схоже, різна в різних тканинах (Simmons et al., 2011). Незважаючи 
на нейротоксичність метилртуті, опосередковану ініціацією пошкоджень ГЕБ, є дані про те, що неорганічна ртуть також виявляє значну цитотоксичність щодо клітин нервової тканини (Takahashi et al., 2017).

Незважаючи на добре відому нейротоксичність органічної ртуті, цитотоксичні ефекти неорганічної ртуті погано вивчені щодо клітин нервової тканини. Важливим відкриттям для розуміння високої цитотоксичності ртуті були результати вивчення деметилювання ртуті в кишковій системі риб та інших організмів (Wang et al., 2017; Manceau et al., 2021).

Неорганічні i органічні форми ртуті поглинаються зябрами 3 подальшим транспортуванням до кровотоку та мозку (Pickhardt et al., 2006). Низька ліпофільність неорганічної ртуті обмежує іiі проникність через ГЕБ. 3 іншого боку, неорганічні та органічні форми ртуті можуть перетворюватися одна в одну мікробіотою кишечнику риб (Yang et al., 2021). Біотрансформація ртуті, опосередкована метилюванням та/або деметилюванням, може вплинути на їi перерозподіл в організмі риб, включаючи мозок. Тому згубний вплив неорганічної ртуті на мозок риби може бути більш масштабним у порівнянні 3 очікуваним. Неорганічна ртуть може перетинати ГЕБ та індукувати цитотоксичність у мозку (Toimela et al., 2004). Завдяки кумулятивному ефекту хронічний вплив низьких доз ртуті може індукувати критичні ушкодження клітин нервової тканини.

Однією $з$ найбільш вивчених аномалій, пов'язаних із цитотоксичністю ртуті у риб, є генерація окисного стресу (Sevcikova et al., 2015; Naija et al., 2018). Крім того, ртуть ініціює мітохондріальну дисфункцію, яка супроводжується множинними молекулярними пошкодженнями, включаючи окислення білка та ДНК (Carocci et al., 2014). Пошкодження ДНК $є$ основною причиною нестабільності геному і зниження життєздатності клітин. Крім того, ртуть виявляє високу спорідненість 3 тіоловими групами i зв'язує відновлений глутатіон та його метаболіти. Це зв'язування пригнічує глутатіон-антиоксидантну систему у мозку (Szunyogh et al., 2015; Carocci et al., 2014). Клітини нервової тканини чутливі до окислювальних пошкоджень i цитотоксичний ефект ртуті може бути пов'язаний зі значною нестабільністю геному в клітинах мозку (van Rensburg et al., 2019) і викликати незворотні порушення життєво важливих функцій мозку.

Наше дослідження показало дозозалежну продукцію РСК, окисно-відновний дисбаланс у мозку райдужної форелі за умов хронічної дії низьких доз ртуті хлориду ртуті. Представлені результати співвідносяться 3 опублікованими раніше даними (Taysi et al., 2019). Показані подібні дані щодо впливу ртуті на перекисне окислення ліпідів, каталазу та глутатіон-S-трансферазу у жовтоперого морського ляща (Harayashiki et al., 2019).

Особливий інтерес останнім часом викликає генотоксична дія ртуті. Поглинання ртуті гліальними клітинами може ініціювати дегенерацію нейронів (Ohgoh, 2000) та метаболічні порушення в мозку (Wang et al., 2015). Виявлене в нашій роботі зниження експресії білка ERCC1 у мозку риб за умов хронічного впливу неорганічної ртуті свідчить про пригнічення системи NERвідновлення ушкоджень ДНК, що може бути однією 3 вагомих причин генотоксичності ртуті. Дефекти ERCC1залежної активності призводять до геномної нестабільності та знижують життєздатність клітин. Генотоксичність впливу ртуті була продемонстрована в клітинах крові звичайного коропа (Gómez-Oliván et al., 2017). Однак вплив неорганічної ртуті на системи відновлення ДНК у мозку риб досі не були представлені у літературі.

Згідно з метою дослідження ми визначали експресію PARP1 як маркера відповіді на ушкодження ДНК та альтернативного механізму іiі репарації. Активована PARP1 рибозилюе ядерні білки, які контролюють структуру хроматину та реплікацію ДНК. Діяльність
PARP1 пов'язана з регулюванням клітинної реакції (Bock, Chang, 2016). Сімейство PARP також відіграє важливу роль у регуляції транскрипції, реакції клітинного стресу, стабільності мРНК, поділі клітин та деградації білка (Ваі, 2015). Крім того, PARP1 каталізує шлях негомологічної репарації ДНК ушкоджень, що є важливим компонентом системи тотальної репарації ДНК. Беручи до уваги, що PARP1 та ERCC1 беруть участь у клітинній відповіді, ініційованій генотоксичним пошкодженням, модуляція їх експресії може відображати життєво важливі адаптивні механізми для підтримки життєздатності клітин.

Генотоксичний ефект неорганічної ртуті відомий (Wyatt et al., 2017), але немає чітких доказів прямої дії неорганічної ртуті на клітинну відповідь на пошкодження ДНК. Беручи до уваги, що PARP1 та ERCC1 беруть участь у відновленні життєво важливих клітинних функцій, результати, отримані в нашому дослідженні, підтверджують гіпотезу про генотоксичну дію ртуті, що супроводжується нестабільністю геному. Більш того, наші результати свідчать про те, що експресія PARP1 та ERCC1 дуже чутлива до токсичної дії ртуті. Отримані дані щодо впливу неорганічної ртуті на експресію PARP1 та ERCC1 в мозку риб представлені вперше. Показане у мозку риб зниження експресії PARP1 та ERCC1 можна оцінювати як перспективний молекулярний біомаркер генотоксичності ртуті.

Навіть незначна кількість ртуті у мозку риб, близько 60 нг/г, викликає адаптаційні механізми та стимулює реакцію на стрес (Biswas, Bellare, 2021). Однак межі адаптогенних доз ртуті залишаються дискусійними та можуть бути різними для окремих філогенетичних груп організмів та окремих типів тканин. Представлені в нашому дослідженні результати підтверджують, що неорганічна ртуть проявляе нейротоксичність, яка пов'язана 3 пригніченням систем репарації ДНК. Крім того, спостережувана у нашому дослідженні продукція РСК може впливати на білок ексцизійної репарації ДНК ERCC1 та полі(АДФ-рибозо)-полімеразу 1 (PARP1). Таким чином, визначену модуляцію ERCC1 i PARP1 можна розглядати як біомаркери нейротоксичності ртуті в мозку риб.

\section{Висновки}

Вплив низьких доз неорганічної ртуті викликає окислювальний стрес, пригнічення експресії білка ексцизійної репарації ДНК ЕRСС1 та полі(АДФ-рибозо)полімерази 1 (PARP1) у мозку райдужної форелі. Інгібування репарації ДНК може призвести до нестабільності геному. Крім того, неорганічна ртуть через індукцію геномної нестабільності може активувати запрограмовану загибель клітин i зниження нервових функцій. Таким чином, зміни в експресї ERCC i PARP1 можна розглядати як біомаркер нейротоксичності ртуті. 3'ясування потенційного ризику забруднення навколишнього середовища сполуками, що містять ртуть, потребує подальшого вивчення.

\section{References}

Amlund, H., Lundebye, A. K., Berntssen, M. H. (2007). Accumulation and elimination of methylmercury in Atlantic cod (Gadus morhua L.) following dietary exposure. Aquatic Toxicology, 83(4), 323-330.

Aschner, M., Aschner, J. L. (1990). Mercury neurotoxicity: mechanisms of blood-brain barrier transport. Neuroscience and Biobehavioral Reviews, 14(2), 169-176.

Bagchi, D., Bagchi, M., Stohs, S. J. (2001). Chromium (VI)induced oxidative stress, apoptotic cell death and modulation of $\mathrm{p} 53$ tumor suppressor gene. Molecular and Cellular Biochemistry, 222(1-2), 149-158. 
Bai P. (2015). Biology of poly(ADP-Ribose) polymerases: The factotums of cell maintenance. Molecular Cell, 58(6), 947-958.

Biswas S., Bellare J. Adaptive mechanisms induced by sparingly soluble mercury sulfide $(\mathrm{HgS})$ in zebrafish: Behavioural and proteomics analysis. Chemosphere, 2021, 270, 129438

Bock, F. J., Chang, P. (2016). New directions in poly(ADPribose) polymerase biology. FEBS Journal, 283(22), 4017-4031.

Brandão, F., Cappello, T., Raimundo, J., Santos, M.A., Maisano, M., Mauceri, A., Pacheco, M., Pereira, P. (2015). Unravelling the mechanisms of mercury hepatotoxicity in wild fish (Liza aurata) through a triad approach: bioaccumulation, metabolomic profiles and oxidative stress. Metallomics: integrated biometal science, 7(9), 1352-1363.

Cariccio, V. L., Samà, A., Bramanti, P., Mazzon, E. (2019). Mercury involvement in neuronal damage and in neurodegenerative diseases. Biological Trace Element Research, 187(2), 341-356.

Carocci, A., Rovito, N., Sinicropi, M.S., Genchi, G. (2014). Mercury toxicity and neurodegenerative effects. Rev Environ Contam Toxicol., 229, 1-18.

Chang, Y., Lee, W.Y., Lin, Y.J., Hsu, T. (2017). Mercury (II) impairs nucleotide excision repair (NER) in zebrafish (Danio rerio) embryos by targeting primarily at the stage of DNA incision. Aquatic Toxicology, 192, 97-104.

Ciardullo, S., Aureli, F., Coni, E., Guandalini, E., Iosi, F., Raggi, A., Rufo, G., Cubadda, F. (2008). Bioaccumulation potential of dietary arsenic, cadmium, lead, mercury, and selenium in organs and tissues of rainbow trout (Oncorhyncus mykiss) as a function of fish growth. Journal of Agricultural and Food Chemistry, 56(7), 2442-2451.

Dos Santos, A. A., Ferrer, B., Marques Gonçalves, F., Tsatsakis, A. M., Renieri, E. A., Skalny, A. V., Farina, M., Rocha, J., Aschner, M. (2018). Oxidative stress in methylmercury-induced cell toxicity. Toxics, 6(3), 47.

Eagles-Smith, C. A., Ackerman, J. T., Willacker, J. J., Tate, M. T., Lutz, M. A., Fleck, J. A., Stewart, A. R., Wiener, J. G., Evers, D. C., Lepak, J. M., Davis, J. A., Pritz, C. F. (2016a). Spatial and temporal patterns of mercury concentrations in freshwater fish across the Western United States and Canada. Science of the Total Environment, 15(568), 1171-1184.

Eagles-Smith, C. A., Wiener, J. G., Eckley, C. S., Willacker, J. J., Evers, D. C., Marvin-DiPasquale, M., Obrist, D., Fleck, J. A., Aiken, G. R., Lepak, J. M., Jackson, A. K., Webster, J. P., Stewart, A. R., Davis, J. A., Alpers, C. N., Ackerman, J. T. (2016b). Mercury in western North America: A synthesis of environmental contamination, fluxes, bioaccumulation, and risk to fish and wildlife. Science of the Total Environment, 15(568), 1213-1226.

García-Medina, S., Galar-Martínez, M., Gómez-Oliván, L. M., Ruiz-Lara, K., Islas-Flores, H., \& Gasca-Pérez, E. (2017). Relationship between genotoxicity and oxidative stress induced by mercury on common carp (Cyprinus carpio) tissues. Aquatic Toxicology, 192, 207-215.

Gasso V. Y., Hahut A. N., Yermolenko S. V., Hasso, I. A., Agca, C. A., Nedzvetsky, V. S., Sukharenko E. V. (2020). Local industrial pollution induces astrocyte cytoskeleton rearrangement in the dice snake brain: GFAP as a biomarker. Biosystems Diversity, 28(3), 250-256.

Giblin, F. J., Massaro, E. J. (1975). The erythrocyte transport and transfer of methylmercury to the tissues of the rainbow trout (Salmo gairdneri). Toxicology, 5, 243-254.

Gómez-Oliván, L. M., Mendoza-Zenil, Y. P., SanJuan-Reyes, N., Galar-Martínez, M., Ramírez-Durán, N., Rodríguez Martín-Doimeadios, R., Rodríguez-Fariñas, N., IslasFlores, H., Elizalde-Velázquez, A., García-Medina, S., Pérez-Pastén Borja, R. (2017). Geno- and cytotoxicity induced on Cyprinus carpio by aluminum, iron, mercury and mixture thereof. Ecotoxicology and environmental safety, 135, 98-105.

Harayashiki, C., Reichelt-Brushett, A., Benkendorff, K. (2019). Behavioural and brain biomarker responses in yellowfin bream (Acanthopagrus australis) after inorganic mercury ingestion. Marine Environmental Research, 144, 62-71.

Has-Schön, E., Bogut, I., Vuković, R., Galović, D., Bogut, A., Horvatić, J. (2015). Distribution and age-related bioaccumulation of lead $(\mathrm{Pb})$, mercury $(\mathrm{Hg})$, cadmium (Cd), and arsenic (As) in tissues of common carp (Cyprinus carpio) and European catfish (Sylurus glanis) from the Buško Blato reservoir (Bosnia and Herzegovina). Chemosphere, 135, 289-296.

Horowitz, H. M., Jacob, D. J., Amos, H. M., Streets, D. G., Sunderland, E. M. (2014). Historical mercury releases from commercial products: global environmental implications. Environmental Science and Technology, 48(17), 10242-10250.

Hussain, B., Sultana, T., Sultana, S., Masoud, M. S., Ahmed, Z., Mahboob, S. (2018). Fish eco-genotoxicology: Comet and micronucleus assay in fish erythrocytes as in situ biomarker of freshwater pollution. Saudi Journal of Biological Sciences, 25(2), 393-398.

Kenšová, R., Kružíková, K., Havránek, J, Haruštiaková, D, Svobodová, Z. (2012). Distribution of mercury in rainbow trout tissues at embryo-larval and juvenile stages. Scientific World Journal, 2012, 652496.

Kirici, M., Nedzvetsky, V. S., Agca, C. A., Gasso, V. Y. (2019). Sublethal doses of copper sulphate initiate deregulation of glial cytoskeleton, NF-kB and PARP expression in Capoeta umbla brain tissue. Regulatory Mechanisms in Biosystems, 10 (1), 103-110.

Koutsoukos, K., Andrikopoulou, A., Dedes, N., Zagouri, F., Bamias, A., Dimopoulos, M. A. (2020). Clinical Perspectives of ERCC1 in Bladder Cancer. International Journal of Molecular Sciences, 21(22), 8829.

Leonard, S. S., Harris, G. K., Shi, X. (2004). Metal-induced oxidative stress and signal transduction. Free Radical Biology and Medicine, 37(12), 1921-1942.

Lin, X., Zhao, J., Zhang, W., He, L., Wang, L., Li, H., Liu, Q., Cui, L., Gao, Y., Chen, C., Li, B., Li, Y. F. (2021). Towards screening the neurotoxicity of chemicals through feces after exposure to methylmercury or inorganic mercury in rats: A combined study using gut microbiome, metabolomics and metallomics. Journal of Hazardous Materials, 409, 124923

Liu, Q., Basu, N., Goetz, G., Jiang, N., Hutz, R. J., Tonellato, P. J., Carvan, M. J., $3^{\text {rd }}$. (2013). Differential gene expression associated with dietary methylmercury (MeHg) exposure in rainbow trout (Oncorhynchus mykiss) and zebrafish (Danio rerio). Ecotoxicology, 22(4), 740-751.

Lohren, H., Blagojevic, L., Fitkau, R., Ebert, F., Schildknecht, S. Leist, M., Schwerdtle, T. (2015). Toxicity of organic and inorganic mercury species in differentiated human neurons and human astrocytes. Journal of Trace Elements in Medicine and Biology, 32, 200-208.

Lohren, H., Bornhorst, J., Fitkau, R., Pohl, G., Galla, H. J., Schwerdtle, T. (2016). Effects on and transfer across the blood-brain barrier in vitro - Comparison of organic and inorganic mercury species. BMC Pharmacology and Toxicology, 17(1), 63.

Manceau, A., Bourdineaud, J.-P., Oliveira, R. B., Sarrazin, S. L. F. Krabbenhoft, D. P., Eagles-Smith, C. A., Ackerman, J. T., Stewart, A. R., Ward-Deitrich, C., del Castillo Busto, M. E., Goenaga-Infante, H., Wack, A., Retegan, M., Detlefs, B., Glatzel, P., Bustamante, P., Nagy, K. L., Poulin, B. A. (2021). Demethylation of methylmercury in bird, fish, and earthworm. Environmental Science and Technology, 55, $1527-1534$

Meena, R., Sathishkumar, P., Ameen, F., Yusoff, A., Gu, F. L. (2018). Heavy metal pollution in immobile and mobile components of lentic ecosystems-a review. Environmental 
Science and Pollution Research International, 25(5), 4134-4148.

Mieiro, C. L., Pacheco, M., Pereira, M. E., Duarte, A. C. (2011). Mercury organotropism in feral European sea bass (Dicentrarchus labrax). Archives of Environmental Contamination and Toxicology, 61(1), 135-143.

Naiija, A., Kestemont, P., Chénais, B., Haouas, Z., Blust, R., Helal, A. N., Marchand, J. (2018). Effects of Hg sublethal exposure in the brain of peacock blennies Salaria pavo: Molecular, Physiological and Histopathological Analysis. Chemosphere, 193, 1094-1104.

Nedzvetsky, V. S., Gasso, V. Ya., Hahut, A. M., Hasso, I. A. (2020b). Influence of cadmium contamination on brain glial cells: consequences and bioindication possibilities. Issues of Steppe Forestry and Forest Reclamation of Soils, 49, 68-83 (in Ukrainian).

Nedzvetsky, V. S., Gasso, V. Ya., Hahut, A. M., Hasso, I. A. (2020a). Glial cytotoxicity of low doses of cadmium as a model of heavy metal pollution influence on vertebrates. Ecology and Noospherology, 31(1), 3-10 (in Ukrainian).

Obrist, D., Kirk, J. L., Zhang, L., Sunderland, E. M., Jiskra, M., Selin, N. E. (2018). A review of global environmental mercury processes in response to human and natural perturbations: Changes of emissions, climate, and land use. Ambio, 47(2), 116-140.

Ohgoh, M., Shimizu, H., Ogura, H., Nishizawa, Y. (2000). Astroglial trophic support and neuronal cell death: influence of cellular energy level on type of cell death induced by mitochondrial toxin in cultured rat cortical neurons. Journal of Neurochemistry, 75, 925-933.

Orihel, D. M., Paterson, M. J., Blanchfield, P. J., Bodaly, R. A., Hintelmann, H. (2007). Experimental evidence of a linear relationship between inorganic mercury loading and methylmercury accumulation by aquatic biota. Environmental Science and Technology, 41(14), 4952-4958.

Pereira, C. S., Guilherme, S. I., Barroso, C. M., Verschaeve, L., Pacheco, M. G., Mendo, S. A. (2010). Evaluation of DNA damage induced by environmental exposure to mercury in Liza aurata using the comet assay. Archives of Environmental Contamination and Toxicology, 58(1), $112-122$.

Pereira, P., Korbas, M., Pereira, V., Cappello, T., Maisano, M., Canário, J., Almeida, A., Pacheco, M. (2019). A multidimensional concept for mercury neuronal and sensory toxicity in fish - From toxicokinetics and biochemistry to morphometry and behavior. Biochimica et Biophysica Acta. General subjects, 1863(12), 129298.

Pereira, P., Puga, S., Cardoso, V., Pinto-Ribeiro, F., Raimundo, J., Barata, M., Pousão-Ferreira, P., Pacheco, M., Almeida, A. (2016). Inorganic mercury accumulation in brain following waterborne exposure elicits a deficit on the number of brain cells and impairs swimming behavior in fish (white seabream - Diplodus sargus). Aquatic Toxicology, 170, 400-412.

Pereira, P., Raimundo, J., Araújo, O., Canário, J., Almeida, A., Pacheco, M. (2014). Fish eyes and brain as primary targets for mercury accumulation - a new insight on environmental risk assessment. The Science of the Total Environment, 494-495, 290-298.

Pereira, P., Raimundo, J., Barata, M., Araújo, O., PousãoFerreira, P., Canário, J., Almeida, A., Pacheco, M. (2015). A new page on the road book of inorganic mercury in fish body - tissue distribution and elimination following waterborne exposure and post-exposure periods. Metallomics: integrated biometal science, 7(3), 525-535.

Pickhardt P.C., Stepanova M., Fisher N.S., Contrasting uptake routes and tissue distributions of inorganic and methylmercury in mosquito fish (Gambusia affinis) and redear sunfish (Lepomis microlophus), Environmental Toxicology and Chemistry. 25 (2006) 2132-2142.
Pillet, M., Castaldo, G., De Weggheleire, S., Bervoets, L., Blust, R., De Boeck, G. (2019). Limited oxidative stress in common carp (Cyprinus carpio, L., 1758) exposed to a sublethal tertiary $(\mathrm{Cu}, \mathrm{Cd}$ and $\mathrm{Zn})$ metal mixture. Comparative Biochemistry and Physiology. Toxicology \& Pharmacology: CBP, 218, 70-80.

Pletz, J., Sánchez-Bayo, F., Tennekes, H. A. (2016). Doseresponse analysis indicating time-dependent neurotoxicity caused by organic and inorganic mercury - Implications for toxic effects in the developing brain. Toxicology, 347-349, 1-5.

Santovito, G., Piccinni, E., Boldrin, F., Irato, P. (2012). Comparative study on metal homeostasis and detoxification in two Antarctic teleosts. Comparative biochemistry and physiology. Toxicology \& Pharmacology: CBP, 155(4), 580-586.

Sevcikova, M., Modra, H., Blahova, J., Dobsikova, R., Kalina, J., Zitka, O., Kizek, R., Svobodova, Z. (2015). Factors affecting antioxidant response in fish from a long-term mercury-contaminated reservoir. Archives of Environmental Contamination and Toxicology, 69(4), 431-439.

Simmons S. O., Fan C. Y., Yeoman K., Wakefield J., Ramabhadran R. (2011). NRF2 oxidative stress induced by heavy metals is cell type dependent. Current Chemical Genomics, 5, 1-12.

Simon, O., Boudou, A. (2001). Direct and trophic contamination of the herbivorous carp Ctenopharyngodon idella by inorganic mercury and methylmercury. Ecotoxicology and Environmental Safety, 50(1), 48-59.

Szunyogh, D., Gyurcsik, B., Larsen, F. H., Stachura, M., Thulstrup, P. W., Hemmingsen, L., Jancsy, A. (2015). $\underline{\mathrm{Zn}}$ (II) and $\mathrm{Hg}(\mathrm{II})$ binding to a designed peptide that accommodates different coordination geometries. Dalton Transactions, 44(28), 12576-12588.

Takahashi, T., Fujimura, M., Koyama, M., Kanazawa, M., Usuki, F., Nishizawa, M., Shimohata, T. 2017. Methylmercury causes blood-brain barrier damage in rats via upregulation of vascular endothelial growth factor expression. PLoS ONE, 12(1): e0170623.

Taysi, M. R., Sogut, D., Nedzvetsky, V. S., Kirici, M., Agca, C. A. (2019). Sublethal doses of inorganic mercury induce dosedependent upregulation of RPA1 content and inhibit p53 expression in the brain of rainbow trout (Oncorhynchus mykiss). Turkish Journal of Agricultural and Natural Sciences, 6(3), 462-476.

Toimela, T., Mäenpää, H., Mannerström, M., Tähti, H. (2004). Development of an in vitro blood-brain barrier modelcytotoxicity of mercury and aluminum. Toxicology and Applied Pharmacology, 195(1), 73-82.

Valavanidis, A., Vlahogianni, T., Dassenakis, M., Scoullos, M. (2006). Molecular biomarkers of oxidative stress in aquatic organisms in relation to toxic environmental pollutants. Ecotoxicology and Environmental Safety, 64(2), 178-189.

van der Oost, R., Beyer, J., Vermeulen, N. P. (2003). Fish bioaccumulation and biomarkers in environmental risk assessment: a review. Environmental Toxicology and Pharmacology, 13(2), 57-149.

van Rensburg, M. J., van Rooy, M., Bester, M. J., Serem, J. C., Venter, C., Oberholzer, H. M. (2019). Oxidative and haemostatic effects of copper, manganese and mercury, alone and in combination at physiologically relevant levels: An ex vivo study. Human \& Experimental Toxicology, 38(4), 419-433.

Vieira, L. R., Gravato, C., Soares, A. M., Morgado, F., Guilhermino, L. (2009). Acute effects of copper and mercury on the estuarine fish Pomatoschistus microps: linking biomarkers to behaviour. Chemosphere, 76(10), 1416-1427.

Wang, W-X., Wong, R. S. K. (2003). Bioaccumulation kinetics and exposure pathways of inorganic mercury and methylmercury in a marine fish, the sweetlips 
Plectorhinchus gibbosus. Marine Ecology Progress Series, 261, 257-268.

Wang, X., Wu, F., Wang, W. X. (2017). In vivo mercury demethylation in a marine fish (Acanthopagrus schlegeli). Environmental Science and Technology, 51(11), 6441-6451.

Wang, Y., Wang, D., Lin, L., Wang, M. (2015). Quantitative proteomic analysis reveals proteins involved in the neurotoxicity of marine medaka Oryzias melastigma chronically exposed to inorganic mercury. Chemosphere, $119,1126-1133$.

Wyatt, L. H., Luz, A. L., Cao, X., Maurer, L. L., Blawas, A. M., Aballay, A., Pan, W. K., Meyer, J. N. (2017). Effects of methyl and inorganic mercury exposure on genome homeostasis and mitochondrial function in Caenorhabditis elegans. DNA repair, 52, 31-48.

Yang, T. T., Liu, Y., Tan, S., Wang, W. X., Wang, X. (2021). The role of intestinal microbiota of the marine fish (Acanthopagrus latus) in mercury biotransformation. Environmental Pollution, 277, 116768.

Zheng, W., Aschner, M., Ghersi-Egea, J. F. (2003). Brain barrier systems: a new frontier in metal neurotoxicological research. Toxicology and Applied Pharmacology, 192(1), $1-11$. 